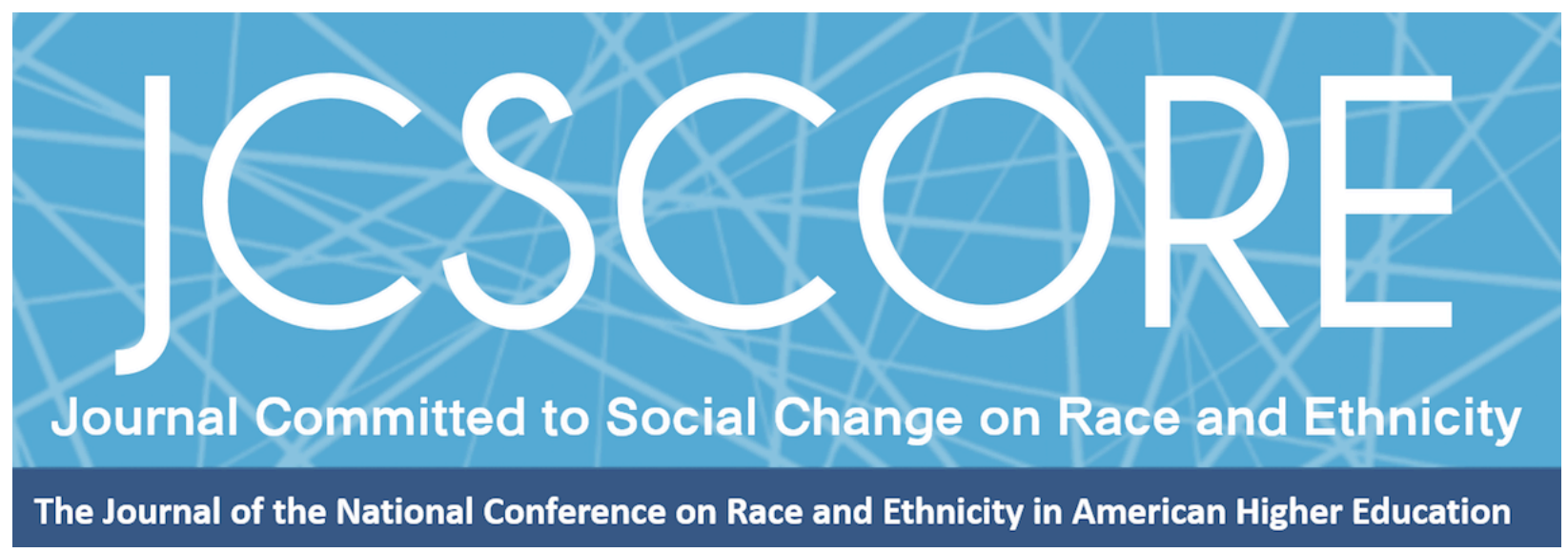

\title{
REPRESENTATIONS MATTER: SERVING NATIVE STUDENTS IN HIGHER EDUCATION
}

Adrienne Keene

Native Appropriations

Journal Committed to Social Change on Race and Ethnicity

Volume 1, Issue 1 | 2015

Copyright $\odot 2015$ Board of Regents of The University of Oklahoma on behalf of the Southwest Center for Human Relations Studies.

Permission of the Publisher is required for resale or distribution and for all derivative works, including compilations and translations. Quoting small sections of text is allowed as long as there is appropriate attribution. 
Journal Committed to Social Change on Race and Ethnicity | 2015

\section{Representations Matter: Serving Native Students in Higher Education}

Adrienne Keene

Native Appropriations

I have, in the past, pulled together a collection of photos of all the stereotypes of American Indians that one could fit into a single breakfast meal (Keene, 2012). From Land-O-Lakes butter, to Calmut baking powder, Indian Head corn meal, Sue Bee honey, Orangina "Indien", on and on, the list of products featuring stereotypical Indians grew. And that's just for breakfast. We are surrounded by these images everyday, following us into shopping malls and grocery stores, featured in Halloween costumes and Disney movies—Native peoples are only ever represented as a stock set of stereotypes, including: Savage warriors, subservient squ*ws, or mystical shamans, and always set in the historic past, in contrast to contemporary modernity. In the national limelight, our nation is embroiled in a debate as to whether a racial slur for Native peoples accompanied by a disembodied, dehumanized head of a stereotypical Indian should be allowed to remain as a professional football mascot. Or at a more basic level, whether that same combination of racial slur+stereotype is honoring to Native peoples. Representations of Native peoples beyond this narrow set of stereotypes are completely invisible. When is the last time that we saw a mainstream representation of a Native professor, doctor, lawyer, or even an everyday neighbor in jeans?

These largely negative stereotypes are the only images our society sees of Native peoples. They are the images that are burned in our brains from the first watching of Peter Pan to weekly Monday night football, and they matter. These 
stereotypes collapse over 566 federally recognized tribes and hundreds more state and non-federally recognized tribes, each with their own unique language, culture, and history into a single Hollywood Indian monolith, erasing the distinctions that make us who we are as Native peoples. In the process of placing us in the historic past (and therefore extinct), or as fantasy creatures, it obscures our ongoing strengths, triumphs, and advances; but also obscures the ongoing real and pressing challenges in our communities as well. If Native peoples are only situated in the imaginations of the public, we will never have the support and understanding we need to move our communities forward.

Media often presents the argument that Native peoples have "bigger issues" to deal with than stereotypes and mascots, but research tells us that these images represented in social have real effects. Fryberg, Markus, Oyserman, and Stone (2008) demonstrated that when shown stereotypical imagery of Native Americans, Native students' measures in self-esteem, community worth, and possible selves went markedly down. More disturbingly, the same process resulted in raised self-esteem for white students. Fryberg et al.'s research demonstrates that these images are not only negatively affecting Native youth, they are also promoting and serving to reinforce systems of white supremacy.

More recent research on Native representations has demonstrated that Native peoples are not just misrepresented in the media; we are completely invisible. Tukachinsky, Mastro, and Yarchi (2015) found in an analysis of primetime television between 1989 and 2009 that Native characters ranged between $0.0 \%-.6 \%$ of the overall numbers. In raw numbers, that translates to three Native characters. Three, in 20 years 
Journal Committed to Social Change on Race and Ethnicity | 2015

of data (Tukachinsky, Mastro, \& Yaruchi, 2015). This invisibility has real effects on how Native peoples understand, "who they are and what they see as possible for themselves" (Fryberg \& Stephens, 2010, p. 115). Without counter-narratives or positive representations for Native students to draw upon, their ability to imagine themselves in the future is limited. In this environment of invisibility, every representation takes on increased importance (Leavitt, Covarrubias, Perez, \& Fryberg, 2015).

As an educational researcher, my research focuses on American Indian, Alaska Native, and Native Hawaiian students navigating the college process, and this invisibility carries through to higher education as well. Native students make up less than $1 \%$ of students nationally, and only .5\% of university faculty are American Indian or Alaska Native (Ginder, S.A., and Kelly-Reid , 2013; Chronicle of Higher Education, 2014). When I started graduate school on the East Coast, I found myself as the only Native doctoral student in my program, and the invisibility felt incredibly acute. I had no Native faculty at my school, and went through several years of coursework without encountering any Native educational scholars on any of my syllabi. It became normalized for me to hear faculty talk about our "four race/ethnicity society" (Black, White, Latino, and Asian), and see slide after slide of educational data that completely erased the existence of me, my family, my community, and nearly 2 million other Indigenous peoples in the U.S.

In addition, I was interacting with classmates who had never met a Native person before, and said incredibly hurtful comments constantly—without even realizing the depth of their ignorance. It took me my first semester, and a trip to Urban Outfitters at the start of the "tribal trends" in fashion, to make the connection between these 
ubiquitous stereotypes in fashion, the media, and popular culture, and the stereotypes and invisibility I felt in the classroom. It was out of this frustration that I started my blog, Native Appropriations ${ }^{1}$, to catalog, deconstruct, and critique these representations, with the goal of changing the ways mainstream America views Native peoples.

To me, the ways that Native peoples are represented in society and the experiences of Native students are inextricably linked. In my research, each of my students have stories upon stories of daily microaggressions from fellow students, staff, and faculty, as well as the experience of the weight of being one of the only Native peoples in an educational space—and having to represent for millions of diverse Native perspectives, cultures, and histories in and out of the classroom. For example, on a campus visit, shadowing one of my students ${ }^{2}$, Megan, through her Chemistry lab, I watched as her classmates peppered her with questions about her heritage, asking if she was "registered" or had Native "garb." She handled it with grace, gently correcting and guiding her classmates, but admitted later that these interactions are daily occurrences. Another student, Duca, told me about encountering classmates in headdresses at his Halloween birthday party. Bryan relayed a story of his classmate in his competitive BA/MD program telling him, on several occasions, "You're the only guy in this program that is an Indian, and you got the scholarship because you're Indian." How can we expect Native students to be successful if they are tasked with not only learning, but also correcting and teaching others at every turn due to the rampant stereotyping and invisibility of Indigenous peoples?

\footnotetext{
${ }^{1}$ Nativeappropriations.com

${ }^{2}$ Student names are pseudonyms
} 
Through their mere presence on campus, Native students like Megan, Duca, and Bryan are challenging Native peoples' stereotypes and creating positive representations for Indian Country, as well as their non-Native peers. This notion of college-going as stereotype breaking is something that many students understand, even before they enter post-secondary education. At College Horizons, a pre-college access program for Native students, I sat with Xeno, a 16-year-old high school junior from the border town of a small Native community in Nevada, and asked him why he felt it was important for Natives to go to college. We had previously been talking about how his college plans were very important to his family, but he tied the broader goals of creating more collegeeducated Native students to breaking stereotypes. I found his answer deeply profound, and want to share it in full:

Oh, that's a great question. Because every day l'm asked a question at my high school, different every day, but relatively in the same aspect, "Do you go to pow-wows? Do you live in a teepee? Hey, do you ride a horse and shoot bow and arrows?" I mean, they're jokes, some of them are jokes, [but] some of them are real questions. Even though I smile every time I get asked, it really hurts me...I feel like I'm irritated because everyone still oppresses us and is still, like...they're still racist. And I know they're joking, but it still hurts on the inside and you can't just go out and tell them that because they won't care. And I feel like to break stereotypes is really the main goal.

I know traditions and family and connection is great, but even if we have all that stuff there will still be Natives out there that have to live through stereotypes every day. And I feel that to go to college is to break those stereotypes. To raise up the percentage of [Natives at] colleges is to break stereotypes. Just to get us further on and put us off the government would be great. And it's really sad to me that there's still people out there that think that we're still savages, and it just bothers me a lot. So, I think to break stereotypes would be great for other Natives. That's the main reason why. 
Journal Committed to Social Change on Race and Ethnicity | 2015

I was struck with Xeno's understanding of the connection between stereotypes and the conditions back home. Embedded in his answer are deeper reasons for college attainment- "to get us farther and off the government"-speaking to the power of educated tribal members to make positive change and assert sovereignty and selfdetermination in our communities, but he also believes that the creation of counterstereotypes is key in creating inter-group understanding and reducing racism toward Native peoples, a notion supported by psychological research in other communities of color (Power, Murphy, and Coover, 1996).

Given this climate of stereotypes and invisibility, what can we, as faculty, administrators, researchers, and community members, do to counter over 500 years of misrepresentations and stereotypes that are clearly affecting our Native students? We can remember that representations matter. We can look at our recruitment practices for students and faculty, we can look at our syllabi, look at our campus programming, our research partners, and see who is represented, and how. We are all socialized in the same American system, one that teaches little to no Native history in schools, that erases the existence of contemporary Native peoples, and that still places Natives as mascots and costumes, so we need to recognize our own blind spots and biases-and work actively to counteract them. We have a responsibility to our Native students, to constantly learn and not let our ignorance paralyze us.

On a more specific level, there are questions we can ask ourselves on college and university campuses to help improve representations on several fronts. First and foremost, who is our local Native community? Who are the Native peoples whose lands our campus occupies? How is that relationship acknowledged and cultivated? It is 
essential to acknowledge that even in states where there are no federally recognized tribes-there are still Native peoples. Second, faculty and educators look at your syllabi, your data, and your lecture slides. How are Native peoples represented? Do you have readings by Native scholars? Do you acknowledge that the data you are utilizing has shortcomings by not including Native peoples? Are all your references to Native people historic, stereotypical, or by non-Native outsiders? For administrators, how is your campus recruiting Native students and faculty? What kind of mentorship or support do you offer for Native students and faculty? What spaces have been created for Native students to congregate together and form community? Finally, how do we as a community support students in making their degrees relevant to Indian country?

Much of being an Indigenous person is rooted in relationships—relationships with the land, with the ancestors, and with one another. We as Native peoples need real allies to partner with us. We need faculty and administrators who are going to put forth the extra effort to get to know their students, who aren't going to ask them if they live in a teepee or tell them they "don't look Indian." But Indigenous relationships do come with responsibility, and an expectation of reciprocity. It is important to shift the weight of responsibility from the Native students themselves, and take up our end of the relationship. We can't ask the students to do it alone. It's important to let them develop their leadership capacity and find their voice, but the role of university settings is to support students as well. In Cherokee, we have a word, gadugi, that means "working together toward a common goal that benefits the overall community." College can be the ultimate enacting of gadugi-we, as a community, can work together to help Native students succeed. As more and more Native students graduate, we are creating an 
Journal Committed to Social Change on Race and Ethnicity | 2015

entire generation of living counter-stereotypes who are able to make positive change for Indian Country. It is important to recognize that even though their numbers may still be small, Native students and people are more than Hollywood stereotypes and football mascots, and to both campus communities and Native communities, those representations matter. 


\section{References}

Chronicle of Higher Education. (2014). Almanac of Higher Education 2014. The Chronicle of Higher Education. Retrieved from: http://chronicle.com/section/Almanac-of-Higher-Education/801/

Fryberg, S., Markus, H. R., Oyserman, D., \& Stone, J. M. (2008). Of warrior chiefs and Indian princesses: The psychological consequences of American Indian mascots. Basic and Applied Social Psychology, 30, 208-218.

Fryberg, S. A., \& Stephens, N. M. (2010). When the world is colorblind, American Indians are invisible: A diversity science approach. Psychological Inquiry, 21(2), 115-119.

Ginder, S.A., \& Kelly-Reid, J.E. (2013). Postsecondary Institutions and Cost of Attendance in 2012-13; Degrees and Other Awards Conferred, 2011-12; and 12Month Enrollment, 2011-12: First Look (Provisional Data) (NCES 2013-289rev). U.S. Department of Education. Washington, DC: National Center for Education Statistics.

Keene, A. (2012, July 24). I eat stereotypes like you for breakfast. Native Appropriations. Retrieved from: http://nativeappropriations.com/2012/07/i-eatstereotypes-like-you-for-breakfast.html

Leavitt, P. A., Covarrubias, R., Perez, Y. A., \& Fryberg, S. A. (2015). "Frozen in Time": The Impact of Native American Media Representations on Identity and SelfUnderstanding. Journal of Social Issues, 71(1), 39-53.

Tukachinsky, R., Mastro, D., \& Yarchi, M. (2015). Documenting Portrayals of Race/Ethnicity on Primetime Television over a 20-Year Span and Their Association with National-Level Racial/Ethnic Attitudes. Journal of Social Issues, 71(1), 17-38.

Pavel, D. M., Skinner, R., Farris, E., Cahalan, M, Tippeconnic, J., \& Stein, W. (1998). American Indians and Alaska Natives in Postsecondary Education. U.S. Department of Education, National Center for Education Statistics; Washington, DC. 
Journal Committed to Social Change on Race and Ethnicity | 2015

Power, J. G., Murphy, S. T., \& Coover, G. (1996). Priming Prejudice How Stereotypes and Counter-Stereotypes Influence Attribution of Responsibility and Credibility among Ingroups and Outgroups. Human communication research, 23(1), 36-58. 